Jambura Physics Journal
p-ISSN: 2654-9107 e-ISSN: 2721-5687
Journal homepage: http://ejurnal.ung.ac.id/index.php/JPJ

\title{
APPLICATION OF DISCOVERY LEARNING MODELS TO LIGHT MATERIALS TO IMPROVE STUDENT LEARNING OUTCOMES
}

\author{
Kristina Uskenat ${ }^{*}$, Kadek A.C Adelia ${ }^{2}$ \\ 1,2 Universitas San Pedro, Jl Veteran No 1 Fatululi, Kupang 85111, Indonesia \\ Email: istinuskenat@gmail.com
}

Received: 23 February 2021. Accepted: 27 April 2021. Published: 30 April 2021

\author{
ARTICLE INFO \\ Keywords: \\ Discovery learning; \\ learning outcomes \\ How to cite: \\ Uskenat, K. and Adelia, \\ K.A.C. (2021). Application \\ of Discovery Learning \\ Models to Student \\ Learning Outcomes. \\ Jambura Physics Journal, \\ 3(1), 16-23. \\ DOI: \\ https://doi.org/10.34312 \\ /jpj.v3i1.10065
}

\begin{abstract}
This study aims to describe the results of the application of the discovery learning model on the subject matter of light in class VIIIC students of SMP Negeri 8 Kupang even semester of the 2019/2020 academic year. This research is descriptive. This research was conducted at SMP Negeri 8 Kupang for the 2019/2020 school year. The subjects in this study were researchers and 22 students of class VIIIC at SMP Negeri 8 Kupang, even semester, 2019/2020 academic year. The techniques used to collect data in this study are observation and tests. Based on the results of the descriptive analysis of the research data, it shows that in general, the application of the discovery learning model for the subject matter of light for students is optimal. In detail, the researcher's ability to manage to learn is obtained which includes: planning, implementing, and evaluating learning, including in the good category. The learning outcomes test (THB) of students for cognitive learning outcomes tests on learning implementation activities which include: preliminary activities, core activities, closing activities, time allocation, and class atmosphere are all in the very high category and cognitive achievement for each lesson plan is all complete.
\end{abstract}

\section{Introduction}

The era of globalization has become a reality that must be faced by the people and nation of Indonesia. Changes that take place so fast and the emergence of various challenges as a result of globalization, education is required to be able to make a significant contribution (Rusniati, 2015). 21st-century education recommends four strategies for education to be successful: First, learning to learn, namely how students can dig up information around them from the explosion of information itself. Second, learning to be, where students are expected to be able to recognize themselves and be 
Uskenat, K. and Adelia, K.A.C/ Jambura Physics Journal (2021) Vol. 3 (1): 16-23

able to adapt to their environment. Third, learning to do, which is in the form of actions or actions to bring up ideas related to science and technology. Fourth, learning to be together, which contains how we live in a society that is interdependent with one another so that we can compete healthily and work together and be able to respect others (Misnawati, 2016).

In a changing social situation, ideally, education is not only oriented to the past and present but should be a process that anticipates and talks about the future (Ilyas, 2012). Education should look far into the future and think about what students will face in the future. A good education is an education that does not only prepare students for a profession or position but to adjust the problems they face in everyday life (Sitepu, 2019). To create students who can adapt to changes and developments in technology science and competence cannot be separated from curriculum development.

Curriculum 2013 is a further step in Competency-Based Curriculum Development which was initiated in 2004 and KTSP 2006 which includes competency attitudes, knowledge, and skills in an integrated manner (Sujana, 2014). Any changes in the curriculum must also be followed by educators who are responsible for implementing learning in schools and are also one of the main factors that determine the quality of education (Tahir, 2017).

Educators are at the forefront of creating quality human resources. Educators deal directly with students in class through the learning process. It is in the hands of educators that quality students will be produced, both in terms of skills (expertise), emotional maturity, and morally and spiritually. Thus, future generations will be produced who are ready to live with the challenges of their times (Paryadi, 2015).

Administratively, the development of educators' careers is increasingly clear with performance references as the basis for the self-development of educators (Ririn Nuraini, 2019). Educators must be wise in determining an appropriate model that can create conducive classroom situations and conditions so that the teaching and learning process can take place according to the expected goals. Based on this, educators need to understand the characteristics of the material, students, and learning methodology in the learning process, especially about the selection of modern learning models (Mahmudah, 2018).

The Discovery learning model is a model for developing active learning methods of students by finding themselves, investigating themselves, so the results obtained will be loyal and long-lasting in memory, not easily forgotten by students. By learning discovery, children can also learn to think analytically and try to solve their problems, and find their concepts and principles in learning (Munir \& Sholehah, 2019).

The assessment system in the discovery learning model can be done using tests or non-tests. The assessment used can be in the form of cognitive assessment, processes, attitudes, or an assessment of the work of students. If the form of assessment is in the form of a cognitive assessment, the discovery learning model can use a written test. If the form of assessment uses an assessment of the process, attitudes, or work results of students, then the implementation of the assessment can be done by observation (Mulyati \& Wardono, 2019). Light is a subject matter that has many experiments and is related to the personal lives of students so that students can solve their problems and discover existing concepts and principles. 


\section{Methode}

\subsection{Types of research}

This type of research used in this research is descriptive research. Descriptive research aims to describe or describe a situation objectively. Among them, it describes the ability of educators to manage learning and the completeness of learning outcomes.

\subsection{Research design}

The design in this study was a one-group pretest-posttest design (Iswara et al., 2018), there is a pretest (initial test) before being given treatment to students and there is a posttest after being given treatment to students. Thus the treatment results can be known to be more accurate because they can compare the conditions before being treated. This design can be described as follows:

$$
\begin{array}{lll}
\mathrm{O}_{1} \times \mathrm{O}_{2} & \mathrm{O}_{1} & : \text { Pretest } \\
& \mathrm{X} & : \text { Treatment (application of discovery learning models) } \\
& \mathrm{O}_{2} & : \text { Posttest }
\end{array}
$$

\subsection{Data collection technique}

The techniques used to collect data in this study are as follows:

\section{Observation}

Observation is the activity of collecting data by conducting direct research on the environmental conditions of the object of research that support research activities, to obtain a clear picture of the condition of the research object (Elva Nuraina, 2017). In this study, observations are used to obtain data about the ability of educators in carrying out learning

2. Test

The test is a set of questions that must be answered, must be responded to, or a task that the test person should perform. The test is used to measure the extent to which a student has mastered the lessons conveyed, especially in the cognitive aspects (Seftiani, 2019). In this study, the test was used to obtain data regarding the completeness of indicators and student learning outcomes, before and after the application of the discovery learning model.

The instrument used was the learning management observation sheet with the application of the discovery learning model in planning, implementing, and evaluating learning. While the instrument used to determine completeness indicators and learning outcomes of students during the learning process is the learning outcome test (THB). THB contains questions related to the subject matter of Light that must be done by students before and after the learning process. The instruments used in the learning outcomes test include questions in the form of multiple-choice.

\subsection{Research procedure}

The steps were taken by researchers in implementing this research is as follows:

1. Develop learning tools and instruments used, namely: Learning Implementation Plan (RPP), Student Teaching Materials (BAPD), and Grid and Learning Outcomes Test (THB)

2. Perform validation by two experts in the field of study to know the appropriateness of these devices in research 
3. Give a pre-test

4. Doing learning activities

5. Provide post-test

\subsection{Data analysis technique}

In this research, the data analysis technique used this research is quantitative descriptive analysis techniques that include the ability of educators in managing learning, completeness of student learning outcomes, by applying discovery learning models.

The formula used to calculate the reliability of the ability of educators in managing learning is :

Percentage of Agreement $=\left(1-\frac{A-B}{A+B}\right) \times 100 \%$

Information:

A: The frequency of the behavioral aspects observed by the observer giving the high frequency

B: The frequency of the behavioral aspects observed by the observer who gives the low frequency

While the proportion of learning completeness can be calculated using the formula:

$$
\begin{aligned}
& \mathrm{P}_{\mathrm{IHB}}=\frac{\mathrm{B}}{\mathrm{N}} \\
& \text { PIHB }: \text { Proportion Correct } \\
& \mathrm{B}: \text { : The scores obtained by students } \\
& \mathrm{N}: \text { Maximum score }
\end{aligned}
$$

\section{Result and Discussion}

The research data obtained were analyzed using descriptive analysis techniques in the form of calculating the average score and proportion.

\subsection{Results of the Analysis of Educators' Ability in Managing Learning}

Observation and assessment were carried out by two observers who were teachers of science subjects at SMP Negeri 8 Kupang. Both of them assess based on assessment guidelines in the form of learning management observation sheets that apply discovery learning models. Observations of learning management include learning planning, learning implementation, and learning evaluation. Assessment of the implementation of learning is assessed during the learning process, while planning and evaluation of learning are assessed using planning and evaluation of learning by looking at the tools used. The results of the assessment can be seen in Table 1.

Based on Table 1 shows that the average reliability of the learning management assessment instrument by applying the discovery learning model is $97 \%$ for learning planning, $97.3 \%$ for learning implementation, and $96 \%$ for learning evaluation. An instrument is said to be good if the reliability coefficient is $\geq 0.75$ or $\geq 75 \%$ (Nasrah et al., 2015). Thus, the instrument prepared is in a good category and it can be concluded that overall the researcher's ability to manage the implementation of learning is good, meaning that the researcher can manage the implementation of learning that applies 
Table 1. Instrument Reliability Analysis Results Learning Management

\begin{tabular}{llllll}
\hline \multirow{2}{*}{ No } & \multirow{2}{*}{ Observed aspects } & \multicolumn{3}{c}{ Instrument Reliability } & \multirow{2}{*}{ Average } \\
\cline { 3 - 4 } & & RPP 01 & RPP 02 & RPP 03 & \\
\hline 1 & Learning Planning & $97 \%$ & $96 \%$ & $98 \%$ & $97 \%$ \\
2 & Implementation of Learning & $97 \%$ & $96 \%$ & $99 \%$ & $97,3 \%$ \\
3 & Learning Evaluation & $96 \%$ & $96 \%$ & $96 \%$ & $96 \%$ \\
\hline
\end{tabular}

the discovery learning model. Based on the results of data analysis, the researcher's ability to plan to learn, evaluate learning, and carry out learning activities that apply the discovery learning model, it appears that the reliability coefficient is $\geq 0.75$, so this instrument is suitable for use in data collection.

\subsection{Completeness of Cognitive Learning Outcomes}

The completeness of the students' cognitive learning outcomes was assessed using the THB instrument which was distributed to 22 class VIIIC students. Data from the results of the Cognitive analysis of students showed that the average value of the THB Cognitive completeness of 22 students for the initial test and final test was 0.41 and 0.84 with an average increase in the proportion of 0.43 , the categories were complete. In more detail, the data from the cognitive THB analysis can be seen in Figure 1.

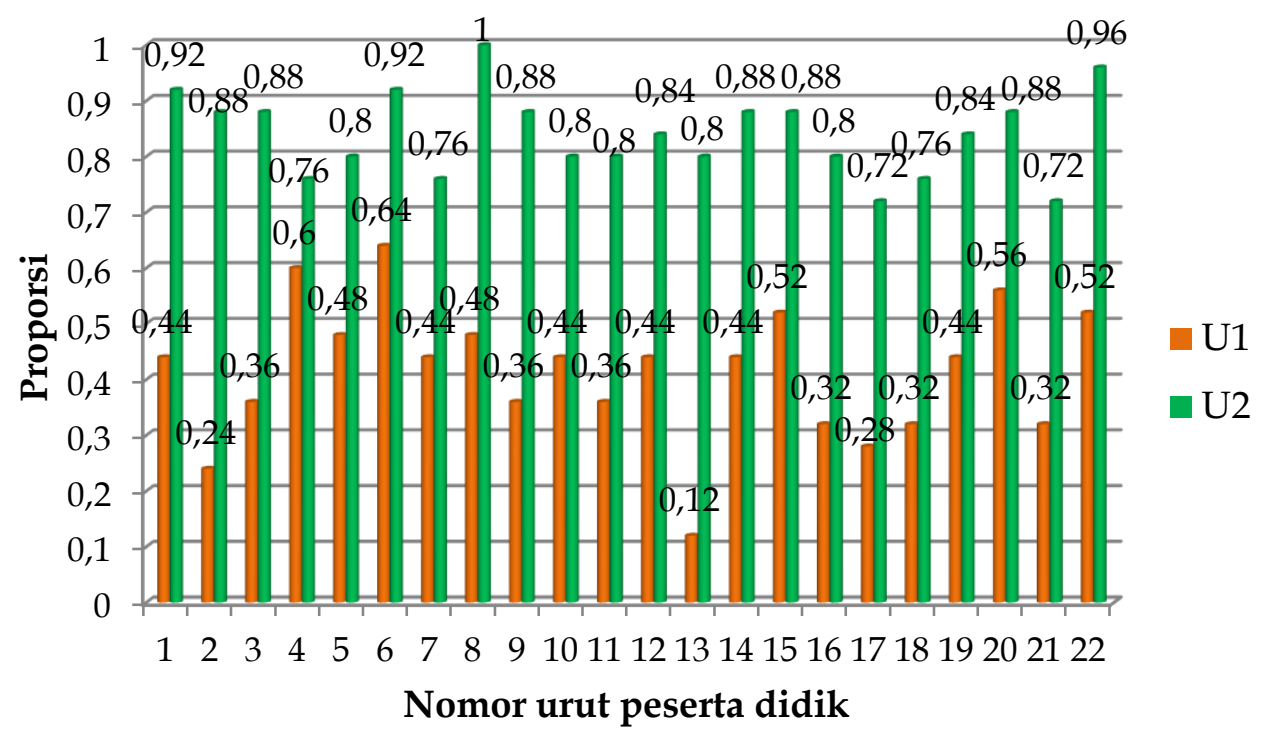

Figure 1. Diagram of the results of analysis of cognitive learning outcomes

Figure 1 shows that the scores of students' cognitive learning outcomes on the initial test (U1) ranged from 0.12 to 0.64 with an average of 0.41 . Meanwhile, the final test (U2) ranged from 0.72 to 0.96 with an average of 0.84 . Based on Figure 1, the highest U2 cognitive PTHB score is 1.00 and the lowest is 0.72 . This is because during learning students do not pay attention to the learning process so that important things that are conveyed by researchers are usually just missed.

In the learning process, all students complete the learning process after being given treatment and 2 students do not complete the learning process after being given treatment. Overall it can be said that the class is complete in learning, this is following 
Uskenat, K. and Adelia, K.A.C/ Jambura Physics Journal (2021) Vol. 3 (1): 16-23

that a class is said to be complete if $80 \%$ of all students in the class concerned to meet the criteria for $\mathrm{P} \geq 0.75$ (Rizal, 2014).

In this learning planning activity, the aspects that are assessed are Student Teaching Materials, Student Worksheets (LKPD), and Learning Implementation Plans (RPP). The average score for the assessment of learning planning by applying the discovery learning model for RPP 01, RPP 02, and RPP 03 is 3.60; 3.64; and 3.62. The total average score for the BAPD, RPP, and LKPD tools is 3.62 with a good category. In this learning evaluation activity, the educator prepares an instrument in the form of a cognitive learning outcome test that is adjusted to 10 indicators of learning outcomes. learning evaluation for RPP 01, RPP 02, and RPP 03 THB is 4.00. The results of data analysis show that the ability of educators to manage learning by applying discovery learning models is good.

In carrying out learning in the class the aspects that are assessed include preliminary activities, core activities, closing activities, time management, and class atmosphere.

Based on the data on the ability of educators to carry out learning activities that apply the discovery learning model, it can be seen that the total average score of the five aspects (introduction, core activities, cover, time management, and classroom atmosphere) is 3.52 which is included in the good category which means educators. able to manage the implementation of learning that applies the discovery learning model.

Based on Figure 1, the highest U2 cognitive PTHB score is 1.00 and the lowest is 0.72. This is because during learning students do not pay attention to the learning process so that important things conveyed by educators are usually just missed.

\section{Conclusion}

Educators' ability in managing subject matter learning light on class VIIIC students of SMP Negeri 8 Kupang with applying the discovery learning model is good. Which include: lesson planning, implementation of learning, and evaluation learning are included in both categories with their respective scores 3.62; 3.52; 3.83 and the completeness of the learning outcomes of class VIIIC SMP Negeri 8 students Kupang Light subject matter in learning activities with apply discovery learning model of 22 students overall complete with a mean proportion for cognitive THB of 0.84 .

\section{Acknowledgment (Optional)}

The author would like to thank SMP Negeri 8 Kupang and the VIIIC grade students who have helped me in conducting research.

\section{References}

Elva Nuraina, F. S. (2017). Pengaruh sanksi perpajakan terhadap kepatuhan wajib pajak orang pribadi di Kantor Pelayanan Pajak Pratama Madiun. EQUILIBRIUM : Jurnal Ilmiah Ekonomi Dan Pembelajarannya, 5(1), 45. https://doi.org/10.25273/equilibrium.v5i1.1005 
Uskenat, K. and Adelia, K.A.C / Jambura Physics Journal (2021) Vol. 3 (1): 16-23

Ilyas, M. (2012). Keefektifan Assesmen Autentik dalam Pembelajaran Matematika. Jurnal Dinamika, 03(1), 64-76.

Iswara, W., Gunawan, A., \& Dalifa, D. (2018). Pengaruh Bahan Ajar Muatan Lokal Mengenal Potensi Bengkulu Terhadap Hasil Belajar Siswa. Jurnal PGSD, 11(1), 17. https://doi.org/10.33369/pgsd.11.1.1-7

Mahmudah, M. (2018). Pengelolaan Kelas: Upaya Mengukur Keberhasilan Proses Pembelajaran. Jurnal $\quad$ Kependidikan, 53-70. https://doi.org/10.24090/jk.v6i1.1696

Misnawati, A. Y. (2016). Penerapan Pendekatan Saintifik Untuk Meningkatkan Keterampilan Proses Pada Siswa Kelas Iii Sekolah Dasar. Jurnal Pendidikan Guru Sekolah Dasar, 1(1), 94-101. https:/ / doi.org/10.17509/jpgsd.v1i1.6549

Mulyati, S., \& Wardono. (2019). Kreativitas Matematis Siswa Pada Pembelajaran Discovery Learning Dengan Media Berbasis Android Studio. PRISMA, Prosiding Seminar Nasional Matematika, 2, 788-797.

Munir, M., \& Sholehah, H. (2019). Metode Pembelajaran Dengan Pendekatan Discovery Learningdalam Mengembangkan Kemampuan Berpikir Kreatif. Elementeris: Jurnal Ilmiah Pendidikan Dasar Islam, 1(2), 1. https://doi.org/10.33474/elementeris.v1i2.4786

Nasrah, Jasruddin, \& Tawil, M. (2015). Pengembangan perangkat pembelajaran fisika berbasis pendekatan contexstual teaching and learning (CTL) untuk memotivasi dan meningkatkan hasil belajar fisika peserta didik kelas VIII SMP Negeri 1 balocci pangkep. Jurnal Pendidikan Fisika, 5(2), 235-248.

Paryadi, P. (2015). Upaya Kepala Sekolah Meningkatkan Kompetensi Profesionalisme Guru Pendidikan Bahasa Indonesia di SMA. Manajer Pendidikan.

Ririn Nuraini. (2019). Pengembangan Self-Esteem Sebagai Upaya Peningkatan... 341. 341366.

Rizal, D. (2014). Meningkatkan Hasil Belajar Siswa Melalui Pembelajaran Kooperatif Berbantuan Media Gambar di Kelas IV SD Inpres 15 Wara Pantoloan. 5(5), 108-115.

Rusniati. (2015). Pendidikan Nasional danTantangan Globalisasi: Kajian Kritik terhadap pemikiran A. Malik Fajar. Jurnal Ilmiah Didaktika, 16(1), 105-128.

Seftiani, I. (2019). Alat Evaluasi Pembelajaran Interaktif Kahoot pada Mata Pelajaran Bahasa Indonesia di Era Revolusi Industri 4 . 0. Prosiding Seminar Nasional Bulan Bahasa (Semiba) 2019, 284-291.

Sitepu, S. (2019). Efektivitas Bahan Ajar Dengan Alur Model Pembelajaran Problem 
Uskenat, K. and Adelia, K.A.C/ Jambura Physics Journal (2021) Vol. 3 (1): 16-23 Based Learning Terhadap Kemampuan Kemampuan Pemecahan Masalah Mahasiswa Prodi Matematika Uhn. Sepren, 1(01), 38-47. https://doi.org/10.36655/sepren.v1i01.73

Sujana, I. G. (2014). Jurnal Widya Acharya FKIP Universitas Dwijendra ISSN NO. 2085-0018 Oktober 2014. Widya Acharya FKIP Universitas Dwijendra, 20850018(2085), 26-35.

Tahir, W. (2017). Pengembangan Manajemen Sumber Daya Manusia Terhadap Peningkatan Mutu Pendidikan. Inspiratif Pendidikan, 6(1), 1. https://doi.org/10.24252/ip.v6i1.3578 